\title{
KESTABILAN MODEL PETRI NET DARI SISTEM PEMBAYARAN TAGIHAN LISTRIK PT. PLN (Persero) RAYON AMBON TIMUR
}

\section{The Stability of Electricity Bill Payment System in PT. PLN (Persero) Rayon East Ambon Modelled by Petri Net}

\section{Zumrotus Sya'diyah ${ }^{*}$}

\section{Program Studi Pendidikan Matematika STKIP Gotong Royong Masohi} Kota Masohi Maluku Tengah, 97514, Indonesia

Corresponding author e-mail: *zuma.yakuza@gmail.com

\begin{abstract}
Abstrak
Dalam penelitian ini dikembangkan hasil dari penelitian mengenai sistem pembayaran tagihan listrik PT. PLN (Persero) Rayon Ambon Timur yang sebelumnya telah dimodelkan menggunakan Petri Net. Penelitian ini membahas tentang kestabilan dari model yang telah dibentuk. Kestabilan sistem yang telah dimodelkan dengan Petri Net dianalisis menggunakan Teori kestabilan Lyapunov berkenaan dengan Petri Net. Hasil yang diperoleh menunjukkan bahwa model yang telah dibentuk oleh peneliti sebelumnya merupakan model yang tidak stabil namun dapat distabilkan. Hal ini disebabkan karena adanya transisi yang bersifat always enable dalam model Petri Net yang telah dibentuk. Selanjutnya, dalam penelitian ini juga diberikan model baru yang stabil dengan mengurangi salah satu transisi dari model sebelumnya.
\end{abstract}

Kata Kunci : Kestabilan Lyapunov, Petri Net, Sistem Pembayaran.

\section{Abstract}

This research develops the previous one of the electricity bill payment system in PT. PLN (Persero) Rayon East Ambon modelled by Petri Net. The previous researcher had built the Petri Net model of this payment system. In this research, we determine whether the system modelled before is stable or not. This stability will be analysed using the Lyapunov stability theory related to the Petri Net. The result shows that the electricity bill payment system modelled by Petri Net before is not stable but can be stabilized. This can be caused there is a transition which is 'always enable' in the modelled which is built. This research also performs a stable model of Petri Net that represents the electricity bill payment system with deleting the 'always enable' transition.

Keywords: Lyapunov Stability, Payment System, Petri Net.

Article info:

Submitted: $01^{\text {st }}$ March $2021 \quad$ Accepted: $02^{\text {nd }}$ October 2021

How to cite this article:

Z. Sya'diyah, "KESTABILAN MODEL PETRI NET DARI SISTEM PEMBAYARAN TAGIHAN LISTRIK PT. PLN (Persero) RAYON AMBON TIMUR”, BAREKENG: J. Il. Mat. \& Ter., vol. 15, no. 04, pp. 601-606, Dec. 2021

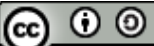

This work is licensed under a Creative Commons Attribution-ShareAlike 4.0 International License. Copyright @ 2021 Zumrotus Sya'diyah 


\section{PENDAHULUAN}

PT PLN (Persero) adalah sebuah BUMN yang mengurusi semua aspek kelistrikan yang ada di Indonesia. Direktur Utamanya saat ini adalah Zulkifli Zaini. Hampir seluruh masyarakat memanfaatkan jasa listrik yang diberikan oleh PT. PLN. Banyak produk yang telah dihasilkan oleh PT. PLN terkait dengan pelayanan sambungan listrik kepada masyarakat. Diantaranya adalah listrik pintar dimana masyarakat dapat mengatur sendiri pemakaian dan pembelian token listrik sesuai dengan kebutuhan. Meskipun demikian, masih banyak pula masyarakat yang masih memanfaatkan jasa sambungan listrik model lama. Pembayaran jasa sambungan listrik model lama ini dapat dilakukan dengan 2 cara, yakni pembayaran secara online lewat aplikasi dan pembayaran langsung ke kantor PT. PLN [8]. Kantor ini juga melayani kebutuhan terkait listrik masyarakat. Layanan seperti pengajuan pemasangan listrik, pengajuan naik tegangan, cek tagihan listrik PLN, pembayaran listrik hingga komplain. Selain dari berkunjung langsung, saat ini masyrakat sudah bisa melakukan cek rekening saldo listrik secara online, dan bayar listrik online dengan PLN token (dalam [11] dan [4]).

Telah banyak penelitian terkait dengan antrian. Teori antrian terkait dengan queueing system, namun belum banyak dibahas dimana antrian sebagai suatu sistem even diskrit. Di antara sedikit pembahasan mengenai antrian sebagai suatu sistem even diskrit adalah penelitian yang telah dilakukan oleh Wattimena, Pentury, dan Lesnussa [15] yang telah membentuk suatu Petri Net yang merepresentasikan sistem pembayaran tagihan listrik langsung ke kantor PT. PLN. Penelitian tersebut menggunakan Petri Net dengan 7 place dan 8 transisi. Telah dibahas pula coverability tree dari model yang telah dibentuk. Namun dalam pembahasannya belum dibahas tentang kestabilan maupun bentuk stabil dari model yang telah dibentuk. Untuk itu, dalam penelitian ini akan dianalisis kestabilan dari model Petri Net dari sistem pembayaran listrik dengan menggunakan teori kestabilan Lyapunov. Selain itu, akan dipaparkan pula bentuk stabil dari model Petri Net.

\section{METODE PENELITIAN}

Penelitian ini dilakukan melalui 3 tahapan, yaitu menganalisis kestabilan dari sistem yang telah dibentuk oeh peneliti sebelumnya, selanjutnya menentukan model atau bentuk Petri Net lain yang representatif dengan memodifikasi model sebelumnya (mengidentifikasi penyebab dari ketidakstabilan dan menghilangkannya), kemudian bentuk model Petri Net baru diperiksa kembali kestabilannya. Berikut ini akan disampaikan teori utama yang digunakan dalam penelitian. Diantaranya adalah teori mengenai Petri Net dan kestabilan Lyapunov berkenaan dengan Petri Net.

\subsection{Petri Net}

Petri Net adalah himpunan 4-pasang $(P, T, A, w)$ dimana $P$ menyimbolkan himpunan berhingga place dalam Petri Net, yaitu $\left\{p_{1}, p_{2}, p_{3}, \cdots, p_{n}\right\}, T$ menotasikan himpunan berhingga transisi dalam Petri Net, yaitu $\left\{t_{1}, t_{2}, t_{3}, \cdots, t_{n}\right\}$, dan kemudian $A$ adalah himpunan semua $\operatorname{arc}$ (busur/panah) yang menghubungkan antara place yang satu dengan yang lain dalam Petri Net. Sedangkan $w$ adalah fungsi bobot dari arc (busur/panah) [1] dan [5].

Petri net dapat juga direpresentasikan dengan menggunakan matriks. Terdapat dua matriks representasi dari Petri Net, yaitu matriks backward incidence dan matriks forward incidence. Kedua matriks tersebut memiliki ukuran yang sama, yakni $m \times n$ dengan $m$ adalah jumlah place dalam Petri Net dan $n$ menyatakan jumlah transisi dalam Petri Net.

Elemen-elemen dari matriks backward incidence adalah bobot arc (busur/panah) yang menghubungkan place ke transisi. Sedangkan matriks forward incidence memiliki elemen-elemen yang merupakan bobot arc yang menghubungkan transisi ke place. Matriks backward incidence dan matriks forward incidence dapat dinyatakan juga sebagai berikut [5]:

dan

$$
A_{b}(i, j) \stackrel{\text { def }}{=} w\left(p_{i}, t_{j}\right)
$$

$$
A_{f}(i, j) \stackrel{\text { def }}{=} w\left(t_{j}, p_{i}\right)
$$


sehingga dipeoleh matriks incidence yang merupakan representasi dari Petri Net secara menyeluruh sebagai berikut:

$$
A=A_{f}-A_{b}
$$

Informasi mengenai Petri Net ini dapat dilihat lebih lengkap dalam [3], [1], [7], dan [12].

\subsection{Kestabilan Lyapunov dari Petri Net}

Suatu sistem yang dimodelkan dengan Petri Net dikatakan stabil jika terdapat $m$ vektor dengan semua elemennya bernilai positif, misal $\Phi$, atau dengan kata lain, dapat ditemukan suatu vektor $\Phi$ yang strictly positive sedemikian hingga berlaku [9]:

$$
\Delta v=e^{T} A^{T} \Phi \leq 0
$$

Karena vektor firing $e$ selalu tak negatif (minimal terdapat satu elemen dari vektor $e$ yang tak nol), maka pertidaksamaan (4) cukup dibuktikan dengan:

$$
A^{T} \Phi \leq 0
$$

Selanjutnya suatu sistem yang dimodelkan dengan Petri Net dapat distabilkan apabila dapat ditemukan suatu vektor firing terhadap transisi yang mempunyai, misal $e$, sedemikian hingga berlaku [10]:

$$
A e \leq 0
$$

Informasi yang lebih jelas mengenai Kestabilan Lyapunov dari suatu Petri net dapat dilihat dalam [13], [14], [5] and [6].

\subsection{Model Petri Net dari Sistem Pembayaran Tagihan Listrik di PT. PLN (Persero) Rayon Ambon Timur [15]}

Dalam penelitian yang dilakukan oleh Wattimena, Pentury, dan Lesnussa [15], telah dibentuk suatu model Petri Net dari sistem Pembayaran Tagihan Listrik di PT. PLN (Persero) Rayon Ambon Timur. Adapun Petri Net yang telah dibentuk dapat dilihat pada Gambar 1 berikut ini.

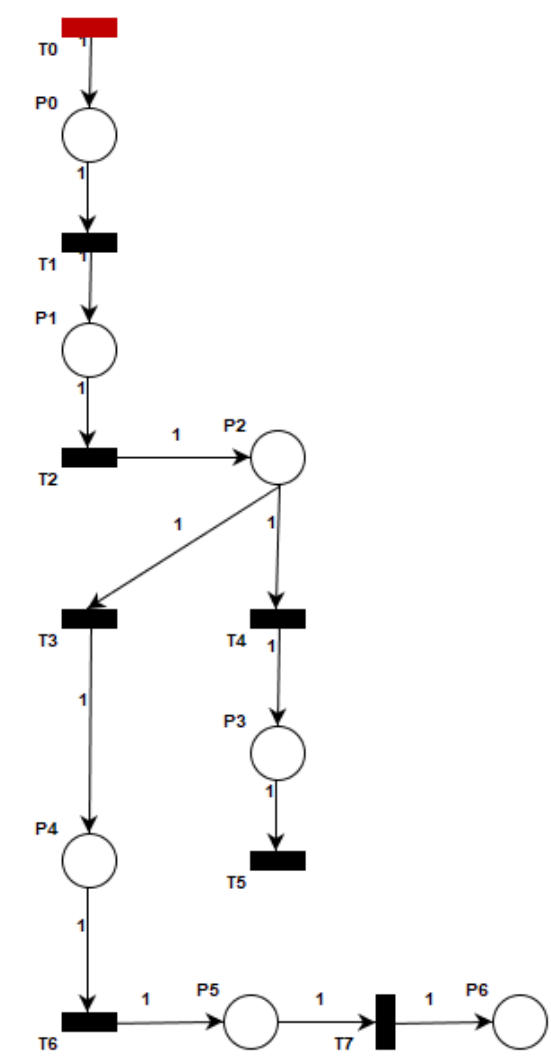

Gambar 1. Model Petri Net Sistem Pembayaran Tagihan Listrik 


\section{Keterangan:}

$P_{0}$ : Pelanggan datang ke Kantor PT. PLN

$P_{1}$ : Pelanggan mengantri dan siap dilayani

$P_{2}$ : Pengecekan nomor tagihan

$P_{3}$ : Pelanggan ke bagian koreksi

$P_{4}$ : Pengecekan tagihan bulan lalu

$P_{5}$ : Pelanggan membayar tagihan di loket pembayaran

$P_{6}$ : Pelanggan pulang

$T_{0}:$ Sumber (source)

$T_{1}$ : Pelanggan mengambil nomor antrian

$T_{2}$ : Pelayanan dimulai

$T_{3}$ : Pelanggan tidak berstatus terlambat bayar

$T_{4}$ : Pelanggan berstatus terlambat bayar

$T_{5}$ : Perhitungan denda keterlambatan pembayaran

$T_{6}$ : Pelanggan siap membayar tagihan

$T_{7}$ : Proses pembayaran tagihan listrik selesai

Dari Petri Net pada Gambar 1, diperoleh matriks incidence sebagai berikut:

$$
A=\left[\begin{array}{cccccccc}
1 & -1 & 0 & 0 & 0 & 0 & 0 & 0 \\
0 & 1 & -1 & 0 & 0 & 0 & 0 & 0 \\
0 & 0 & 1 & -1 & -1 & 0 & 0 & 0 \\
0 & 0 & 0 & 0 & 1 & -1 & 0 & 0 \\
0 & 0 & 0 & 1 & 0 & 1 & -1 & 0 \\
0 & 0 & 0 & 0 & 0 & 0 & 1 & 0 \\
0 & 0 & 0 & 0 & 0 & 0 & 0 & 1
\end{array}\right]
$$

\section{HASIL DAN PEMBAHASAN}

Dalam pembahasan ini, akan dipaparkan kestabilan dari sistem pembayaran tagihan listrik yang telah dimodelkan dengan Petri Net pada Gambar 1 serta memiliki matriks representasi incidence pada persamaan (7). Kestabilan ini dianalisis menggunakan teori kestabilan Lyapunov sebagai berikut.

Misalkan suatu vektor $\Phi=\left[\Phi_{1}, \Phi_{2}, \cdots, \Phi_{7}\right]^{T}$ dengan mensubstitusikannya pada pertidaksamaan (5). Diperoleh vektor $\Phi$ sebagai berikut:

$$
\Phi_{1}=\Phi_{2}=\cdots=\Phi_{7}=0
$$

Tampak bahwa, diperoleh vektor $\Phi$ yang tidak strictly positive. Sehingga dapat disimpulkan bahwa sistem yang dimodelkan menggunakan Petri Net pada Gambar 1 bersifat tidak stabil. Hal ini disebabkan karena terdapat transisi yang selalu enable pada model Petri Net Gambar 1. Selanjutnya, akan dicari apakah sistem tersebut dapat distabilkan atau tidak dengan menggunakan pertidaksamaan (6).

Dari pertidaksamaan (6) dengan memisalkan $e=\left[e_{1}, e_{2}, \cdots, e_{8}\right]^{T}$ dapat diperoleh persamaan elemen vektor firing e sebagai berikut:

$$
e_{1}=e_{2}=e_{3}=e_{7}=e_{8}=0
$$

dan

$$
\begin{array}{r}
-e_{4}+e_{6}=0 \Leftrightarrow e_{4}=e_{6} \\
e_{5}-e_{6}=0 \Leftrightarrow e_{5}=e_{6}
\end{array}
$$

Dari persamaan (8), (9) dan (10) dan dengan memisalkan $e_{6}=k, k \in \mathbb{N}$ dapat diperoleh vektor firing sebagai berikut:

$$
e=[0,0,0, k, k, k, 0,0]^{T}
$$

Hal ini menunjukkan bahwa sistem yang dimodelkan dengan Petri Net pada Gambar 1 bersifat dapat distabilkan. Untuk itu, dibentuk suatu model Petri Net yang merepresentasikan sistem pembayaran tagihan listrik dengan menghilangkan penyebab ketidakstabilan sistem, yaitu dengan menghilangkan transisi yang selalu enable, yakni $T_{0}$. Model Petri Net hasil dari modifikasi Gambar 1 dapat dilihat pada Gambar 2. 
Dari Gambar 2 diperoleh matriks forward incidence sebagai berikut:

$$
A_{f}=\left[\begin{array}{lllllll}
0 & 0 & 0 & 0 & 0 & 0 & 0 \\
1 & 0 & 0 & 0 & 0 & 0 & 0 \\
0 & 1 & 0 & 0 & 0 & 0 & 0 \\
0 & 0 & 0 & 1 & 0 & 0 & 0 \\
0 & 0 & 1 & 0 & 1 & 0 & 0 \\
0 & 0 & 0 & 0 & 0 & 1 & 0 \\
0 & 0 & 0 & 0 & 0 & 0 & 1
\end{array}\right]
$$

Sedangkan matriks backward incidence dari Gambar 2 adalah:

$$
A_{b}=\left[\begin{array}{ccccccc}
1 & 0 & 0 & 0 & 0 & 0 & 0 \\
0 & 1 & 0 & 0 & 0 & 0 & 0 \\
0 & 0 & 1 & 1 & 0 & 0 & 0 \\
0 & 0 & 0 & 0 & 1 & 0 & 0 \\
0 & 0 & 0 & 0 & 0 & 1 & 0 \\
0 & 0 & 0 & 0 & 0 & 0 & 1 \\
0 & 0 & 0 & 0 & 0 & 0 & 0
\end{array}\right]
$$

Sehingga diperoleh matriks incidence secara keseluruhan adalah:

$$
A=A_{f}-A_{b}=\left[\begin{array}{ccccccc}
-1 & 0 & 0 & 0 & 0 & 0 & 0 \\
1 & -1 & 0 & 0 & 0 & 0 & 0 \\
0 & 1 & -1 & -1 & 0 & 0 & 0 \\
0 & 0 & 0 & 1 & -1 & 0 & 0 \\
0 & 0 & 1 & 0 & 1 & -1 & 0 \\
0 & 0 & 0 & 0 & 0 & 1 & -1 \\
0 & 0 & 0 & 0 & 0 & 0 & 1
\end{array}\right]
$$

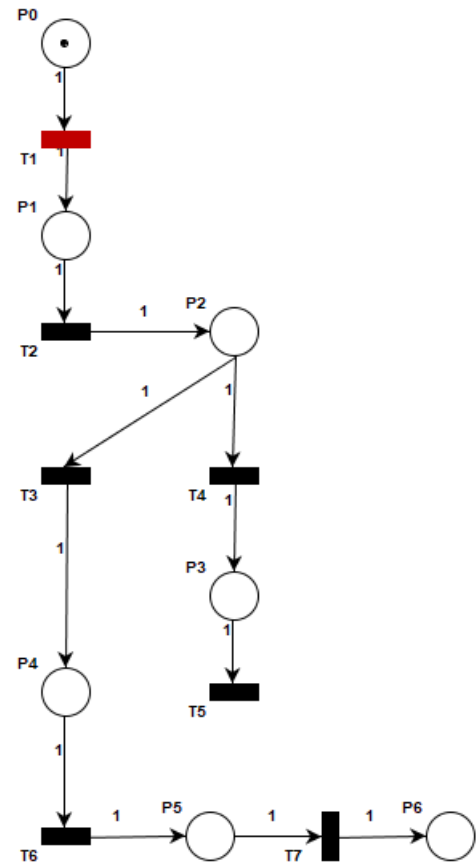

Gambar 2. Modifikasi Model Petri Net Sistem Pembayaran Tagihan Listrik

Selanjutnya kestabilan dari hasil modifikasi sistem pembayaran tagihan listrik yang telah dimodelkan dengan Petri Net pada Gambar 2 dianalisis menggunakan teori kestabilan Lyapunov. Dimisalkan suatu vektor $\Phi=$ $\left[\Phi_{1}, \Phi_{2}, \cdots, \Phi_{7}\right]^{T}$ dengan mesubstitusikannya pada pertidaksamaan (5). Diperoleh vektor $\Phi$ sebagai berikut:

$$
\Phi_{1}=\Phi_{2}=\cdots=\Phi_{7}
$$

Dengan memisalkan $\Phi_{7}=s, s \in \mathbb{R}^{+}$, maka diperoleh: 


$$
\Phi=[s, s, s, s, s, s, s]^{T}
$$

Tampak bahwa, diperoleh vektor $\Phi$ yang strictly positive. Sehingga dapat disimpulkan bahwa sistem yang dimodelkan menggunakan Petri Net pada Gambar 2 bersifat stabil.

\section{KESIMPULAN}

Berdasarkan pembahasan yang telah dilakukan, dapat ditarik kesimpulan bahwa sistem pembayaran tagihan listrik yang telah dimodelkan menggunakan Petri Net pada penelitian sebelumnya merupakan suatu bentuk model yang tidak stabil. Hal ini disebabkan karena dalam model tersebut terdapat suatu transisi yang always enable. Meskipun demikian, model Petri Net tersebut masih termasuk ke dalam bentuk yang dapat distabilkan dengan menghilangkan penyebab ketidakstabilan. Sehingga diperoleh bentuk model Petri Net baru hasil modifikasi dari model sebelumnya yang memiliki sifat stabil.

\section{DAFTAR PUSTAKA}

[1] Adhalia, NF, Subiono and Dieky Adzkiya, "Modeling of Water Treatment Plant Using Timed Continuous Petri Nets", AIP Conference Proceedings 1867-020066, doi: 10.1063/1.4994469. American Institute of Physics, 2017.

[2] Adzkiya, D., " Membangun Model Petri Net Lampu Lalu-lintas dan Simulasinya," Tesis, Institut Teknologi Sepuluh Nopember (ITS), Surabaya, 2008.

[3] Hope, Garret, Paul Brodhead, and Seung-yun Kim, "Implementing Timed Petri net for Modeling and Simulation in Card Gameplay", EPiC Series in Computing, Proceedings of $35^{\text {th }}$ International Conference on Computers and Their Applications, Volume 69 ,Pages: 297-306, 2020.

[4] Idris, Muhammad, "Bagaimana Cara Cek Tagihan Listrik PLN?", 24 Juni 2021, [onine]. Tersedia: https://amp.kompas.com/money/read/2021/06/24/084400126/bagaimana-cara-cek-tagihan-listrik-pln [Diakses: 20 September 2021].

[5] Konigsberg, Z.R, "Timed Petri Nets Modeling and Lyapunov/Max-Plus Algebra Stability Analysis for a Type of Queuing Systems", International journal of pure and applied mathematics, Vol. 86, no. 2, 2013.

[6] Konigsberg, Z.R, "Modeling and Stability Analysis of a Communication Network System", Journal of Computer and Communications, Vol. 16, No. 3, page: 176-183, 2015.

[7] Murata,T , "Petri Nets: Properties, Analysis and Applications," Proc. of the IEEE, Vol. 77, pp. 541-574, 2013.

[8] Pamungkas, A. Bayu, "Prosedur Penagihan Rekening Listrik dengan Sistem Tul V-601 dan Sistem PPOB (Payment Point OnLine Bank) Di PT PLN (Persero) Rayon Comal", Skripsi, Universitas Diponegoro, Semarang, 2016.

[9] Retchkiman, Z, “A Mixed Lyapunov-Max-Plus Algebra Approach to the Stability Problem for a two Species Ecosystem Modeled with Timed Petri Nets", International Mathematical Forum, Vol. 5 no. 28, pp. 1393-1408, 2010.

[10] Retchkiman, Z, "The Stability Problem for Discrete Event Dynamical Systems Modeled with timed Petri Nets Using a Lyapunov-Max-Plus Algebra Approach", International Mathematical Forum, Vol. 6 no. 11, pp. 541-566, 2011.

[11] Ridwan, Muhammad, "Informasi Terkini Seputar Kegiatan PT.PLN (Persero) Wilayah Maluku dan Maluku Utara". Idalamat, 27 Desember 2019, [online]. Tersedia: https://idalamat.com/alamat/4453/pt-pln-persero-area-kota-ambon [Diakses: 8 September 2021].

[12] Silva J.R, and P. M. G. D. Foyo, "Timed Petri Nets, Petri Nets" Manufacturing and Computer Science, Vol. 3 no. 1, pp. 31-40, Aug. 2012.

[13] Sya'diyah, Zumrotus, "Kestabilan Lyapunov-Aljabar-Max-Plus pada Sistem Predator-Prey yang Dimodelkan Menggunakan Timed Petri Net dengan Semua Holding Times Diperhitungkan”, Tesis, Institut Teknologi Sepuluh Nopember (ITS), Surabaya, 2011.

[14] Smith, Alwi, "Lyapunov Stability Analysis of Initiation Process in DNA (Deoxyribonucleid Acid) Translation Using Petri Net" Applied Mathematical Sciences Journal. Vol. 11, no. 64, 3153 - 3162, 2017, HIKARI Ltd.

[15] F. Wattimena, T. Pentury dan Y. A. Lesnussa, “Aplikasi Petri Net pada Sistem Pembayaran Tagihan Listrik PT. PLN (Persero) Rayon Ambon Timur”, Jurnal Barekeng, Vol. 6 no. 1, pp. 23 - 30, 2012. 